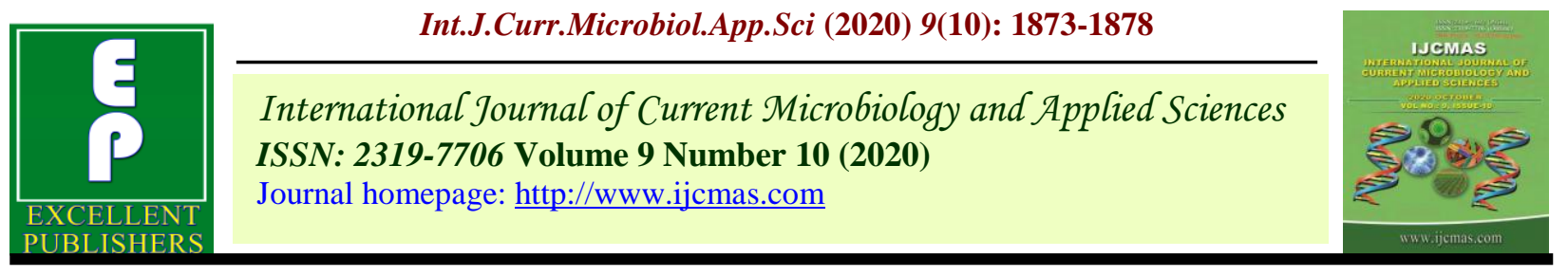

Original Research Article

https://doi.org/10.20546/ijcmas.2020.910.229

\title{
Beneficial Effects of Biostimulants in Various Flower Crops and Ornamental Plants
}

\author{
Syed khudus" and Ajit Kumar \\ Department of Horticulture, College of Agriculture, G.B. Pant university of Agriculture and \\ Technology, Pantnagar, Uttarakhand, India \\ *Corresponding author
}

\section{A B S T R A C T}

\section{Keywords}

Biostimulants,

Organic,

Floriculture

Article Info

Accepted:

15 September 2020

Available Online:

10 October 2020
Agricultural growing practices have been evolving towards organic, sustainable or environmentally friendly systems. The aim of modern agriculture is to reduce inputs without reducing the yield and quality. The identification of organic molecules able to activate plant metabolism may allow an improvement in plant performance in a short period of time and in a cheaper way. Biostimulants are plant extracts and contain a wide range of bioactive compounds that are mostly still unknown. These products are usually able to improve the nutrient use efficiency of the plant and enhance tolerance to biotic and abiotic stresses. In this review, the state of the art and future prospects for biostimulants are reported and discussed. Moreover, particular attention has been paid to intensive agricultural systems such as floricultural crops. In floriculture, biostimulants used in bedding plant production stimulated the growth of plants, which reached the blooming and commercial stages earlier, thus optimizing space in the greenhouse.

\section{Introduction}

The sustainability production of horticultural crops is essential to meet consumer's demand. This is best achieved by increasing the efficient use of resources to make and provide healthy products. In contemporary years, various technological upheavals have been proposed in order to boost the sustainability of production systems, through a remarkable reduction of agrochemicals. An optimistic practice would be the use of substances and/or microorganisms that strengthen plant growth, increase tolerance to unfavorable soil and environmental conditions, and it also increases resource use efficiency. The term "biostimulant" was proposed for these substances and microorganisms by (Zhang and Schmidt, 1997). Plant biostimulants are the materials which include substances and microorganisms which stimulate natural processes when applied to plants or the rhizosphere the main functions of plant biostimulants include nutrient uptake, nutrient efficiency, tolerance to abiotic stresses, increase crop quality. Jardin (2015) proposed seven classes of substances that act as biostimulant namely: Humic and fulvic acids (Canellas et al., 2015), protein hydrolysates, seaweed extracts, chitosan (Pichyangkura and 
Chandchavan, 2015), inorganic compounds, beneficial fungi and bacteria (Ruzzi and Aroca, 2015).

\section{Main categories of biostimulants}

\section{Humic and fulvic acids}

Humic substances (HS) are the natural elements of the soil organic matter, formed from the decomposition of plant, animal and microbial residues, also from the metabolic activity of soil microbes using these substrates. Sources of humic substances (HS) are extracted from naturally humified organic matter (e.g., peat or volcanic soils), from composts and vermicomposts, or from mineral deposits. Humic substances enhance soil fertility, acting on physical, physicochemical, chemical and biological properties of the soil.

Protein hydrolysates and other Ncontaining compounds

Amino-acids and peptides mixtures are obtained by chemical and enzymatic protein hydrolysis from agro-industrial by-products. Other nitrogenous molecules include betaines, polyamines, and non-protein amino acids. These compounds have beneficial effects as biostimulants on plant growth. It regulates enzymes of the TCA cycle, Chelating effects are reported for some amino acids (like proline) which may protect plants against heavy metals but also contribute to micronutrients mobility and acquisition.

\section{Seaweed extracts and botanicals}

Use of fresh seaweeds as a source of organic matter and as fertilizer is ancient in agriculture, but effects of biostimulant have been recorded recently. This prompts the commercial use of seaweed extracts and of purified compounds, which include the polysaccharides laminarin, alginates and carrageenans, and their breakdown products. Other constituents contributing to the plant growth include sterols, micro and macronutrients, N-containing compounds, like betaines, and hormones. Their polysaccharides in soils, contribute to water retention, gel formation, and soil aeration.

\section{Chitosan and other biopolymers}

Chitosan is formed from chitin, a copolymer of N-acetyl-d-glucosamine and Dglucosamine. The physiological effects of chitosan oligomers in plants are the results of the capacity of this poly-cationic compound to bind a wide range of cellular components, including cell wall constituents, plasma membrane and DNA, but also to bind specific receptors involved in defense gene activation, in a similar way as plant defense elicitors. Chitosan used as a biostimulant to stimulate plant growth and abiotic stress tolerance, and as to induce pathogen resistance; however, these responses are complex and they depend on different chitosan-based structures and concentrations as well as the plant species and developmental stage.

\section{Inorganic compounds}

Chemical elements that promote plant growth and may be essential to particular taxa but are not required by all plants are called beneficial elements. The five main beneficial elements are $\mathrm{Si}, \mathrm{Al}, \mathrm{Se}, \mathrm{Na}$ and $\mathrm{Co}$, present in soils and in plants as different inorganic salts and as insoluble forms. These inorganic compounds influence $\mathrm{pH}$, osmotic and redox homeostasis, hormone signaling and enzymes involved in stress response (e.g. peroxidase). Among five beneficial elements $\mathrm{Si}$ is used abundantly as biostimulants, Si alleviates salt, drought, and nutrient stress, as well as stress associated with climatic conditions, minimizes metal and metalloid toxicities. 


\section{Table.1}

\begin{tabular}{|c|c|c|c|c|c|}
\hline Sl No & Bio stimulant & Crop & Application ofbio stimulant & Effect of bio stimulants & References \\
\hline \multirow[t]{3}{*}{1} & \multirow[t]{3}{*}{$\begin{array}{l}\text { Humic } \\
\text { substances }\end{array}$} & Gladiolus & $\begin{array}{l}\text { HA derived from composts is applied with different } \\
\text { concentration doses; corms soaked for } 24 \mathrm{~h} \text { in } \\
\text { treatment solutions }\end{array}$ & $\begin{array}{l}\text { Growth is increased and } \\
\text { promoted early flowering. }\end{array}$ & $\begin{array}{l}\text { Baldotto and Baldotto, } \\
2013 .\end{array}$ \\
\hline & & Chrysanthemum & $\begin{array}{l}\text { HA derived from peat combined with NPK } \\
\text { fertilizers is applied as foliar spray }\end{array}$ & $\begin{array}{l}\text { Increased shoot and root } \\
\text { fresh and dry weight and } \\
\text { flower diameter by } 33 \% \text {. }\end{array}$ & Fan et al., 2014. \\
\hline & & Croton and hibiscus & $\begin{array}{l}\text { HA derived from vermicompost is applied as foliar } \\
\text { spray with different concentration doses }\end{array}$ & $\begin{array}{l}\text { It hastens rooting of } \\
\text { cuttings. }\end{array}$ & Baldotto et al., 2012. \\
\hline 2 & $\begin{array}{l}\text { Protein } \\
\text { Hydrolysates }\end{array}$ & lily & Foliar application & $\begin{array}{l}\text { Reduced the duration of } \\
\text { crop and increased } \\
\text { diameter of flower } \\
\text { buds,stem and bulb dry } \\
\text { weight }\end{array}$ & $\begin{array}{l}\text { De Lucia and Vecchietti, } \\
\text { 2012. }\end{array}$ \\
\hline \multirow[t]{6}{*}{3} & \multirow[t]{6}{*}{$\begin{array}{l}\text { Sea weed } \\
\text { extract }\end{array}$} & Amaranthus tricolor & A. nodosum extract applied as foliar spray & $\begin{array}{l}\text { Increased stalk length of } \\
\text { inflorescences, length, and } \\
\text { number of inflorescences, } \\
\text { the fresh and dry weight } \\
\text { of inflorescences under } \\
\text { salt stress }\end{array}$ & Aziz et al., 2011. \\
\hline & & Marigold & Ecklonia maxima extract applied as foliar spray & $\begin{array}{l}\text { Increased in vegetative } \\
\text { and reproductive growth }\end{array}$ & Van Staden et al., 1994. \\
\hline & & Petunia, Pansy and Cosmos & A. nodosum extract along with N-P-K fertilizer & $\begin{array}{l}\text { Increased length of root, } \\
\text { leaf area and development } \\
\text { of root and shoot in } \\
\text { response to drought stress }\end{array}$ & Neily et al., 2010. \\
\hline & & Paper birch & Seaweed extract & $\begin{array}{l}\text { Increased in chlorophyll } \\
\text { and carotenoids }\end{array}$ & Richardson et al., 2004. \\
\hline & & Tall fescue sod & A. nodosum extract in combination with humic acid & $\begin{array}{l}\text { Increased root mass, and } \\
\text { foliar content of } \\
\text { tocopherol and zeatin } \\
\text { riboside under drought } \\
\text { stress }\end{array}$ & Zhang et al., 2010. \\
\hline & & Turf and forage grasses & A. nodosum commercial extract & $\begin{array}{l}\text { Enhanced ascorbic acid, } \beta- \\
\text { carotene content and } \\
\text { increased antioxidant }\end{array}$ & Kauffman et al., 2007. \\
\hline
\end{tabular}


Int.J.Curr.Microbiol.App.Sci (2020) 9(10): 1873-1878

\begin{tabular}{|c|c|c|c|c|c|}
\hline & & & & $\begin{array}{l}\text { activity of superoxide } \\
\text { dismutase, glutathione } \\
\text { reductase, and ascorbate } \\
\text { peroxidase }\end{array}$ & \\
\hline \multirow[t]{5}{*}{4} & \multirow[t]{5}{*}{ Chitosan } & Chrysanthemum & $\begin{array}{l}\text { Chitosan at } 0.01 \% \text { to } 0.05 \% \text { sprayed Twice on } \\
\text { symptomatic plants }\end{array}$ & $\begin{array}{l}\text { Protected against Oidium } \\
\text { chrysanthemi and Puccinia } \\
\text { horiana. }\end{array}$ & Wojdyła, 2004. \\
\hline & & Gladiolus & $\begin{array}{l}\text { Corm dippedbefore planting with Commercial } \\
\text { chitosan (Biorend) at } 1.5 \% \text { combined with hot } \\
\text { watertreatment }\end{array}$ & $\begin{array}{l}\text { Accelerated corm } \\
\text { emergence, increased } \\
\text { number of flowers } \\
\text { extended vase life and } \\
\text { increased number of } \\
\text { cormlets. }\end{array}$ & García et al., 2009. \\
\hline & & Lisianthus & Chitosan flake at $1 \%$ Added to soil at sowing time & $\begin{array}{l}\text { Enhanced growth, } \\
\text { shortened flowering time } \\
\text { increased number and } \\
\text { weight of flowers. }\end{array}$ & Ohta et al., 1999. \\
\hline & & Rose & $\begin{array}{l}\text { Plant spraying twice weekly after rose powdery } \\
\text { mildew symptoms Chitosan at } 0.01-0.02 \%(\mathrm{w} / \mathrm{v})\end{array}$ & $\begin{array}{l}\text { Protected against } \\
\text { Sphaerotheca pannosa var. } \\
\text { rosae, Peronospora sparsa } \\
\text { and Diplocarpon rosae. }\end{array}$ & Wojdyła, 2004. \\
\hline & & Gloxinia & $\begin{array}{l}\text { Seedling pretreatment and soil application Chitosan } \\
\text { at } 1 \%(\mathrm{w} / \mathrm{v})\end{array}$ & $\begin{array}{l}\text { Promoted seedling growth } \\
\text { and induced earlier } \\
\text { flowering. }\end{array}$ & Ohta et al., 2004. \\
\hline \multirow[t]{2}{*}{5} & \multirow[t]{2}{*}{ Silicon } & Rose & $\begin{array}{l}\text { Two concentrations, i.e., } 50 \text { and } 100 \mathrm{ppm} \text { by } \\
\text { spraying for } 6 \mathrm{~s} \text { every } 8 \mathrm{~min} \text { for } 16 \mathrm{~h} \text { per day Si } \\
\text { applied through the mist }\end{array}$ & $\begin{array}{l}\text { Increased leaflet retention, } \\
\text { the percentage of rooting, } \\
\text { and new leaf emergence }\end{array}$ & $\begin{array}{l}\text { Gillman and Zlesak, } \\
2000 .\end{array}$ \\
\hline & & Carnation & $\begin{array}{l}\text { Potassium silicate }\left(\mathrm{K}_{2} \mathrm{SiO}_{3}\right) \text { with } 0,50 \text {, or } 100 \\
\mathrm{mg} \cdot \mathrm{L}^{-1} \text { in combination with } 0,50 \text {, or } \\
100 \mathrm{mM} \text { sodium chloride }(\mathrm{NaCl}) \text { in Invitro } \\
\text { condition }\end{array}$ & $\begin{array}{l}\text { Enhancement of growth } \\
\text { and resistance to salinity } \\
\text { by Si } 50 \mathrm{mg} \cdot \mathrm{L}^{-1}\end{array}$ & Soundarajan et al.,2015. \\
\hline
\end{tabular}


In conclusion the application of biostimulants in flower crop cultivation allows higher levels of sustainability by the reduction of fertilizers and environmental contamination and, at the same time, increases plant tolerance to abiotic and biotic stresses enhancing internal and external quality. It can be concluded that application of biostimulants can lead to qualitative and quantitative increase in various flower crop production. Thus, biostimulants play a significant role in sustainable flower production.

\section{References}

Asrar, A.A., Abdel-Fattah, G.M., Elhindi, K.M., 2012. Improving growth, flower yield, and water relations of snapdragon (Antirhinum majus L.) plants grown under well-watered and waters tress conditions using arbuscular mycorrhizal fungi. Photosynthetica 50, 305-316.

Aziz, N., Mahgoub, M., Siam, Z., 2011. Growth, flowering and chemical constituents performance of Amaranthus tricolor plants as influenced by seaweed (Ascophyllum nodosum) extract application under salt stress conditions. $J$. Appl.Sci. Res. 7, 1472-1484.

Baldotto, L.E.B., Baldotto, M.A., Soares, R.R., Martinez, H.E.P., Venegas, V.H.A., 2012.Adventitious rooting in cuttings of croton and hibiscus in response to indole butyric acid and humic acid. Rev. Ceres 59, 476-483.

Baldotto, M.A., Baldotto, L.E.B., 2013. Gladiolus development in response to bulb treatment with different concentrations of humic acids. Rev. Ceres 60,138-142.

Canellas, L.P.; Olivares, F.L.; Aguiar, N.O.; Jones, D.L.; Nebbioso, A. and Piccolo, P. 2015. Humic and fulvic acids as biostimulants in horticulture. Scientia Horticulturae, 196: 15-27.

Damodaran, T.; Rai, R.B.; Jha, S.K.; Kannan, R.; Pandey, B.K.; Vijayalaxmi, S.; Mishra, V.K. and Sharma, D.K. 2014. Rhizosphere and endophytic bacteria for induction of salt tolerance in gladiolus grown in sodic soils. Journal of Plant Interactions, 9(1): 577-584.

De Lucia, B., Vecchietti, L., 2012. Type of biostimulant and application method effects on stem quality and root system growth in LA Lily. Eur. J. Hortic. Sci. $77,1-10$.

Fan, H.; Wang, X.; Sun, X.; Li, Y.; Sun, X.Z. and Zheng, C. 2014. Effects of humic acid derived from sediments on growth, photosynthesis and chloroplast ultra stucture in chrysanthemum. Scientia Horticulturae, 177: 118-123.

Gillman, J.H., Zlesak, D.C., 2000. Mist applications of sodium silicate to rose (RosaL. × 'nearly wild') cuttings decrease leaflet drop and increase rooting. Hortic. Sci. 117, 500-503.

Göre, E.M., Altin, N., 2006. Growth promoting of some ornamental plants by root treatment with specific fluorescent Pseudomonads. J. Biol. Sci. 6, 610-615.

Jardin. 2015. Plant biostimulants: Definition, concept, main categories and regulation. Scientia Horticulturae, 196: 3-14.

Jayamma, N., Naik, N.M., Jagadeesh, K.S., 2014. Influence of biofertilizer applicationon growth, yield and quality parameters of Jasmine (Jasminum auriculatum). In: Proceeding of International Conference on Food, Biological and Medical Sciences (FBMS-2014), January 28-29, 2014; Bangkok, Thailand, pp. 28-30.

Kamenidou, S., Cavins, T.J., Marek, S., 2008. Silicon supplements affect horticultural traits of greenhouse-produced ornamental sunflowers. Hortic. Sci. 43, 236-239.

Kauffman, G.L., Kneivel, D.P., Watschke, T.L., 2007. Effects of a biostimulant on theheat tolerance associated with photosynthetic capacity, membrane thermostability, and polyphenol production of perennial ryegrass. Crop Sci. 47,261-267.

Navarro, A., Elia, A., Conversa, G., Campi, P., Mastrorilli, M., 2012. Potted mycorrhizal carnation plants and saline stress: growth, quality and nutritional plant responses. Sci. Hortic. 140, 131-139.

Neily, W., Shishkov, L., Nickerson, S., Titus, D., Norrie, J., 2010. Commercial extract from the brown seaweed Ascophyllum nodosum 
(Acadian (R) ) improves early establishment and helps resist water stress in vegetable and flower seedlings. Hortscience 45, 105-106.

Ohta, K., Taniguchi, A., Konishi, N., Hosoki, T., 1999. Chitosan treatment affects plant growth and flower quality in Eustoma grandiflorum. Hort. Sci. 34, 233-234.

Pichyangkura, R. and Chandchavan, S. 2015. Biostimulant activity of chitosan in horticulture. Scientific Horticulturae, 196: 49-65.

Pornpienpakdee, P.; Singhasurasak, R.; Chaiyasp, P.; Pichyangkura, R.; Bunjongrat, R.; Chadchavan, S. and Limpanavech, P. 2010. Improving the micropropagation efficiency of hybrid Dendrobium orchids with chitosan. Scientia Horticulturae, 124: 490-499.

Pruthvi, P.H.; Naik, B.H.; Shivaprasrd, M. and Bellingappa. 2017. Effect of biostimulants on morphology, flowering and yield of chrysanthemum (Dendranthema grandiflora Tzvelev.) cv. Kolar Local under naturally ventilated polyhouse. The Bioscan, 12(1): 273-276.

Ramos-García, M., Ortega-Centeno, S., Hernández-Lauzardo, A.N., Alia-Tejacal, I.,Bosquez-Molina, E., Bautista-Bãnos, S., 2009. Response of gladiolus (Gladiolusspp.) plants after exposure corms to chitosan and hot water treatments. Sci. Hortic. 121, 480-484.

Richardson, A.D., Aikens, M., Berlyn, G.P., Marshall, P., 2004. Drought stress and paper birch (Betula papyrifera) seedlings: effects of an organic biostimulant on plant health and stress tolerance, and detection of stress effects with instrument-based, noninvasive methods. J. Arboric. 30, 5261.

Ruzzi, M. and Aroca, R. 2015. Plant growthpromoting rhizobacteria act as biostimulants in horticulture. Scientia Horticulturae, 196: 124-134.

Soundarajan, P.; Manivannan, A.; Park, Y.G.; Muneer, S. and Jeong, B.R. 2015. Silicon alleviates salt stress by modulating antioxidant enzyme activities in Dianthus caryophyllus 'Tula'. Horticulture, Environment and Biotechnology, 56(2): 233-239.

Sundar, S.T.; Kannan, M. and Jawaharlal, M. 2014. Off-season flower induction through fertigation and biostimulant spray in Jasminum sambac Ait. The Asian Journal of Horticulture, 9(1): 32-35.

Van Staden, J., Upfold, S.J., Drewes, F.E., 1994. Effect of seaweed concentrate on growth and development of the marigold Tagetes patula. J. Appl. Phycol. 6,427-428.

Wojdyla, A.T., 2004. Chitosan (biochikol 020 PC) in the control of some ornamental foliage diseases. Commun. Agric. Appl. Biol. Sci. 69, 705-715.

Zhang, X. and Schmidt, R.E. 1997. The impact of growth regulators on alpha-tocopherol status of water-stressed Poa pratensis L. International Turfgrass Society Research Journal, 8: 1364-1371.

Zhang, X., Wang, K., Ervin, E.H., 2010. Optimizing dosages of sea weed extractbased cytokinins and zeatin riboside for improving creeping bentgrass heat tolerance. Crop Sci. 50, 316-320.

\section{How to cite this article:}

Syed khudus and Ajit kumar. 2020. Beneficial Effects of Biostimulants in Various Flower Crops and Ornamental Plants. Int.J.Curr.Microbiol.App.Sci. 9(10): 1873-1878.

doi: https://doi.org/10.20546/ijcmas.2020.910.229 